\title{
The Effects of a Professional Development Program on English as a Foreign Language Teachers' Efficacy and Classroom Practice
}

\section{DENIZ ORTAÇTEPE \\ Bilkent University}

\section{AYŞE S. AKYEL Yeditepe University}

The purpose of the present study is twofold: (1) to investigate the relationship between the efficacy of teachers of English as a foreign language (EFL) and their self-reported practice of communicative language teaching (CLT) and (2) to examine the impact of an in-service teacher education program on teachers' efficacy and self-reported and actual practice of CLT. Data came from a Teachers' Background Questionnaire, English Teachers' Sense of Efficacy Scale (Chacon, 2005), Communicative Orientation of Language Teaching (COLT; Spada \& Frönlich, 1995), and the questionnaire version of COLT. Fifty Turkish EFL teachers working in eight schools responded to the questionnaires, and 20 of them were observed. The findings indicate that after the in-service education program, the teachers not only improved their practice of CLT but also became more efficacious. The findings highlight the importance of awareness-raising activities for professional development programs as well as the need for multiple instruments to analyse the extent to which teachers' self-reported beliefs and practices concur with their observed teaching practice.

doi: $10.1002 /$ tesj.185

\section{Although professional development is essential for teachers to meet their new learning needs (Bransford, Darling-Hammond,}


\& LePage, 2005; Lohman, 2000; Richards \& Farrell, 2005), recent studies have revised the assumption that holding the required knowledge and skills is sufficient for effective teaching. Teachers' attitudes and beliefs are also found to contribute to their effectiveness as educators (Bandura, 1997; Pajares, 1992; Tschannen-Moran, Woolfolk Hoy, \& Hoy, 1998). Teacher efficacyin other words, teachers' beliefs in their ability to influence student outcomes (Tournaki \& Podell, 2005) — has been found to be directly related to many positive teacher behaviours and attitudes (Bandura, 1997; Campbell, 1996; Tschannen-Moran et al., 1998; Yost, 2002) as well as student achievement (Henson, 2001; Tschannen-Moran \& Barr, 2004). However, limited research has been conducted on the influence of professional development activities on teacher efficacy (e.g., Eun \& Heining-Boynton, 2007). In Turkey, where the present study was conducted, studies on teacher efficacy mostly focused on science education (Çakıroğlu, Çakıroğlu, \& Boone, 2005; Savran-Gencer \& Çakıroğlu, 2007). The present study aims to explore teacher efficacy in the field of foreign language teaching while investigating the professional development of teachers of English as a foreign language (EFL).

\section{THEORETICAL ROOTS OF TEACHER EFFICACY}

The theoretical roots of teacher efficacy date back to the mid-1970s, starting with the studies of RAND researchers. Since then, two different theories, Rotter's social learning theory and Bandura's social cognitive theory, have dominated the studies conducted on the meaning, measurement, and related factors of teacher efficacy (Tschannen-Moran et al., 1998).

Rotter's social learning theory defines teacher efficacy as the extent to which teachers believe that they can control the reinforcements of their actions; in other words, whether the control of events lay within themselves or the environment. Teachers' beliefs about the power of the external factors as opposed to the influence of internal factors have been labeled as general teacher efficacy, whereas beliefs in their internal power to influence student motivation and learning are named as personal teacher efficacy (Tschannen-Moran et al., 1998). 
According to Bandura's (1997) social cognitive theory, people's beliefs in their efficacy influence them in various ways, such as the actions they take, the choices they make, the amount of effort they put into their struggles, their perseverance towards obstacles and failures, their flexibility for adversity, the level of stress and depression they experience in coping with environmental demands, and the level of accomplishments they ultimately achieve. The higher the levels of efficacy, the greater the effort, persistence, resilience, and the level of achievement will be and vice versa. Bandura (1997) talks about four principal sources of self-efficacy: enactive mastery experiences (i.e., authentic evidence for capability to succeed); vicarious experiences (i.e., the transmission of competencies); verbal persuasion (i.e., social influences that convince someone that she or he possesses certain capabilities); and physiological and affective states, through which people partly judge their capableness, strength, and vulnerability to dysfunction.

Tschannen-Moran et al. (1998) propose an integrated model of teacher efficacy comprising these two strands. In their model, teacher efficacy is defined as "the teachers' belief in their capabilities to organize and execute courses of action required to successfully accomplish a specific teaching task in a particular context" (p. 233). The integrated model comprises two dimensions: the analysis of teaching tasks (i.e., the assessment of the factors that make teaching difficult in relation to the resources that facilitate learning) and the assessment of personal teaching competence (i.e., the teachers' judgments about their personal capabilities such as their knowledge, skills, personal traits, and strategies in relation to their weaknesses). In this model, teacher efficacy results from the cognitive ability to make explicit judgments regarding personal competence in light of an analysis of a particular task in a particular situation.

\section{CURRENT RESEARCH ON TEACHER EFFICACY}

Recent studies on teacher efficacy in first language (L1) contexts have found evidence for relating teacher efficacy to various demographic and contextual factors such as teacher preparation, educational level, school climate, subject area taught, years of 
teaching experience, gender, and age of student (e.g., Campbell, 1996; Woolfolk Hoy \& Burke Spero, 2005) as well as factors related to teaching and learning, such as teachers' adoption of innovative techniques (Ghaith \& Yaghi, 1997), commitment to teaching (Coladarci, 1992), teacher burnout (Betoret, 2006; Skaalvik \& Skaalvik, 2010), classroom management (Woolfolk \& Hoy, 1990), and predictions of student success (Tournaki \& Podell, 2005). The studies also provide evidence for the relationship between teacher efficacy and several professional development activities such as mentoring (Yost, 2002), in-service activities (Fritz, 1995), professional development sessions (Ross \& Bruce, 2007), and teacher research (Henson, 2001).

Although a wide range of studies have been conducted in L1 settings, especially in science or mathematics education (e.g., Ross \& Bruce, 2007), the studies conducted in contexts of English as a second language (ESL, where English is used for official purposes) and English as a foreign language (EFL, where learners have limited exposure to the target language because English is not used officially) are limited to factors such as demographic information, proficiency of language use, and classroom management (Chacon, 2005; Shim, 2001). These studies reveal that teaching satisfaction, role preparedness, classroom management, school stress, peer relationships, and academic emphasis were the variables that distinguished teachers with high efficacy from their low-efficacy counterparts (e.g., Shim, 2001). A positive relationship existed between teachers' self-perceived ability in teaching the target language and the level of teacher efficacy; teachers' efficacy was correlated with self-reported English proficiency levels of the teachers, and teacher efficacy did not seem to have a significant relationship with the methods (either communicative or grammarbased approaches) teachers applied in the classroom and their years of English teaching experience (Chacon, 2005). In Chacon's (2005) study, although the efficacious teachers reported that they used role-plays, games, and simulations in their lessons, when observed, the lessons were mostly teacher-centered, grammar was presented without contextual cues, and interaction among students was rare. To our knowledge, the only study that relates ESL teachers' efficacy to professional development was conducted 
by Eun and Heining-Boynton (2007), who examined the role of possible factors such as teacher efficacy, organizational support, and teaching experience on the extent to which professional development programs influence ESL teachers' use of newly acquired knowledge and skills. However, the results of their study rely on self-reported data rather than classroom observations. Therefore, the present study highlights not only the importance of beliefs on teachers' practices but also the need for classroom observations to analyse the extent to which teachers' beliefs interplay with their real teaching practice.

\section{THE PRESENT STUDY}

\section{The Context of the Study}

The present study aims to explore language teacher efficacy in a foreign language context: Turkey. As stated in Klassen, Tze, Betts, and Gordon's (2011) review article, most teacher efficacy research has been conducted in the United States with U.S. participants. Thus, there is a need for further research exploring teacher efficacy in different cultural settings, because variations in teaching environments can result in different teaching practices as well as different teacher roles and responsibilities (Klassen et al., 2011). Therefore, this study investigates the change, if any, in Turkish EFL teachers' efficacy and teaching practices as a result of a professional development program.

In recent years, there has been a shift in foreign language teaching from traditional grammar-based approaches to more communicative ones such as communicative language teaching (CLT). This shift brings a new role for foreign language teachers. Instead of being the only source of knowledge, the foreign language teacher is now a facilitator who not only creates a classroom climate conducive to language learning but also provides opportunities for students to engage in meaningful communication (Hall, 2011; Richards \& Rodgers, 2004). As also noted in Byram, Gribkova, and Starkey's (2002) report prepared for the Council of Europe, language teachers need "not just knowledge and skill in the grammar of a language but also the ability to use the language in socially and culturally appropriate 
ways" (p. 7). This recent approach takes the notion of communicative competence one step further and aims to cultivate the idea of communicative intercultural competence with a focus on language, culture, and the relationship between them. Despite these shifts in language teaching, CLT, as a "corrective to perceived shortcomings with other approaches and methods, such as Grammar-Translation and the Direct Method" (Bax, 2003, p. 278), still reserves its popularity as an approach that emphasizes the communicative aspects of language.

Similar to many foreign language teaching contexts, English language education in Turkey is still going through a change from grammar-based approaches to communicative ones. Although CLT has occupied most of the teaching, materials development, curriculum design, testing, and teacher training processes of the ELT curricula throughout Turkey (e.g., Coşkun, 2011; İnceçay \& İnceçay, 2009; Kırkgöz, 2008), there are still schools, universities, and language teaching institutions that follow the traditional approaches such as grammar translation or the audiolingual method.

\section{The Professional Development Program of This Study}

The schools from which the data came were in the process of updating their curriculum to follow this change and provide more communicative English language teaching opportunities to their students. With these intentions, the director of eight K-12 foundation schools located in a large city in Turkey made an agreement with the English language teaching (ELT) department of a well-known Turkish university. As a result of this collaboration, the faculty members in the ELT department would not only mentor the English teachers at these eight schools but also design a professional development program to address their needs and interests. After a 2-month preparation/needs analysis period of interviewing the teachers and the coordinators, observing classes, and evaluating the textbooks used, the ELT department designed an in-service teacher education program with the goal of increasing teachers' knowledge and practice of CLT. The program was based on the following objectives: 
1. Engaging teachers in activities for raising their awareness of past experiences, beliefs, practice, and tacit knowledge

2. Involving teachers in the process of identifying their learning needs

3. Engaging teachers in dialogue with colleagues, addressing their practice, beliefs, and the social pressures affecting their work

4. Exposing teachers to new input through interactive seminars and workshops followed by assigned readings on CLT

5. Providing opportunities for reflection on individual teaching practices such as journal writing (Roberts, 1998)

Within this framework, a syllabus aiming at developing and/or improving teachers' practice of CLT was prepared by the English language coordinators at the university. The syllabus included readings on EFL teaching methods with emphasis on CLT (e.g., Larsen-Freeman, 2003; Richards \& Rodgers, 2004) as well as on issues related to reflective practice (e.g., Murray \& Christison, 2011; Richard-Amato, 2003).

Seminars and discussions were conducted to discuss the application of CLT principles in classroom contexts. During the in-service seminars, teachers' dialogue with peers and the coordinators encouraged their active involvement in the learning process. The program aimed not only to raise teachers' awareness about the theoretical and practical aspects of foreign language teaching and CLT, but also to enable them to become reflective practitioners. According to Freeman and Johnson (1998), problems with most language teacher education programs result from the process-product paradigm, which, although aims to provide teachers with discrete amounts of research-driven knowledge, undermines their individual experiences and perspectives. Therefore, the theoretical basis of the program relied on Richards and Farrell's (2005) framework of reflective teaching, which aims to "move [teachers] from a level where they are guided largely by impulse, intuition, or routine to a level where actions are guided by reflection and self-awareness"' (p. 37). As a social constructivist approach (Vygostky, 1978), reflective practice aims to explore each teacher's development in relation to his or her constant exchange with his or her social environment, working relationships, the climate of the school, and the wider social circumstances. According to Freeman and Johnson (1998), understanding one's 
own practice and its impact on others is "the wellspring of reflective practice, classroom inquiry, and ongoing professional development" (p. 412). Thus, in the present study, as part of the professional development program, teachers were assigned reflective thinking tasks (e.g., Richards \& Farrell, 2005; Roberts, 1998) such as writing journals to reflect on their teaching and engaging in dialogue with peers and coordinators concerning their current practices.

One of the English coordinators visited each school once a week. During these visits, in the mornings the coordinator observed the lessons, and in the afternoon gave feedback to the teachers followed by group discussions on the reading assignments and the applicability of the new input. Once a month, all coordinators and the head teachers of the English departments of the schools met and discussed the general problems and possible solutions. The in-service teacher education program organized by the coordinators at the university lasted approximately 8 months in total.

\section{The Aim of the Study and the Research Questions}

The present study aims to examine the effects of an in-service education program on the professional development of Turkish EFL teachers in regards to the change in their teacher efficacy and classroom practice. Therefore, this study addresses the following research questions:

1. What is the relationship between Turkish EFL teachers' efficacy and their self-reported teaching behaviour in the class?

2. To what extent does the in-service teacher education program influence Turkish EFL teachers' efficacy and their self-reported and observed teaching behaviour in the class?

\section{Participants in the Study}

Fifty Turkish EFL teachers (46 female and 4 male) working in these eight schools, teaching seventh, eighth, and ninth graders, participated in the study. Among these 50 teachers, only 20 volunteered for the observations. The teachers were all main course teachers, and the average teaching experience was 6 years. The participating schools were similar to each other in terms of the 
number of students, their social background, and materials used in the English programs.

\section{Data Collection}

Because one of the aims of the study is to examine the impact of an in-service teacher education program on Turkish EFL teachers' efficacy and their self-reported and observed practice of CLT, the data were collected in a pretest and posttest design (see Figure 1).

Fifty teachers were administered the questionnaires, and 20 teachers were observed in each phase of data collection. In this respect, this study is a field study based on both correlational and within-subjects experimental design. It is correlational because, in order to answer the first research question, the strength of the relationship between Turkish EFL teachers' efficacy and their selfreported practice of CLT was investigated. The second research question of this study is based on one group pretest and posttest experimental design, because in order to indicate the impact of the in-service teacher education program on Turkish EFL teachers' efficacy and their self-reported and observed practice of CLT, the following four steps were carried out: (1) administering a pretest measuring the constructs (e.g., administering the questionnaires, observing the lessons), (2) applying the experimental treatment (e.g., in-service teacher education), (3) administering a posttest

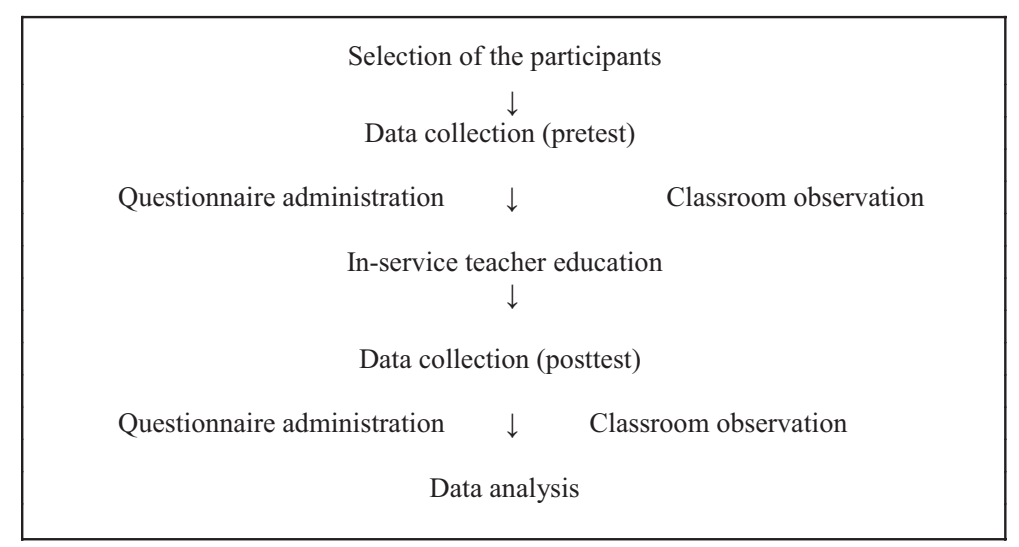

Figure 1. Procedure of the study 
again measuring the constructs, and (4) evaluating the differences attributed to application of the experimental treatment comparing the pretest and posttest results (Ary, Jacobs, Razavieh, \& Sorensen, 2006).

Data came from a teachers' background questionnaire to gain demographic information about the teachers and their background, the English Teachers' Sense of Efficacy Scale (ESTES; Chacon, 2005) to investigate their efficacy, the Communicative Orientation of Language Teaching (COLT) observation scheme (Spada \& Frönlich, 1995) to assess their observed practice of CLT, and the questionnaire version of COLT (QCOLT) to explore their self-reported practice of CLT.

English Teachers' Sense of Efficacy Scale. The adapted version of TSES (Tschannen-Moran \& Woolfolk Hoy, 2001), with 12 items, including 4 items for each of the three dimensions (teachers' efficacy for engaging students learning in EFL, for managing EFL classes, and for implementing instructional strategies to teach EFL), was used to assess the participating teachers' efficacy. This instrument is a 9-point Likert scale with anchors at $1=$ nothing, $3=$ very little, $5=$ some influence, $7=$ quite a bit, $9=$ a great deal. The reliability coefficients of each subscale were .79 for efficacy in engagement, .83 for management, and .81 for instructional strategies.

\section{Communicative Orientation of Language Teaching} observation scheme. The COLT observation scheme is divided into two parts. Part A, which describes classroom events at the level of episode and activity, differentiates the following features: time, activities and episodes, content (focus on form or meaning), content control (control of teacher, teacher and students, and only students), participant organization (whole class, group work, and individual work), student modality (use of skills), and materials (Spada \& Frönlich, 1995). The coding of Part A is done in real time by putting check marks at the appropriate features describing the activity or episode. Each activity and episode is timed so that a calculation of the percentage of time spent on various COLT features can be determined (Spada \& Frönlich, 1995). Part B analyses the communicative features of verbal exchange between teachers and students and/or students and students, and it 
consists of five communicative features: use of the target language, information gap, sustained speech, reaction to form/message, and incorporation of student teacher utterances. The general coding procedure of Part B is done after the observation with the help of audiovisual recordings by placing check marks in the appropriate features for the relevant categories whenever the teacher takes a turn. Each category in Part B is analysed in terms of a proportion of its main feature, that is, counting the number of check marks in a particular category and dividing it by the total of check marks under that feature (Spada \& Frönlich, 1995). At the end of each observation, we listened to the audio recordings and went over the data sheet for Part A to ensure the validity of the observations. Once both of us agreed on all the items on Part A, we listened to the audio recordings one more time to code Part B. Both of us demonstrated agreement in our coding of Part B.

The questionnaire version of COLT. In order to assess teachers' self-reports about how they use communicative language teaching in their lessons, we developed the questionnaire QCOLT, including 56 statements based on the items in the COLT observation scheme and discussions in the professional literature on CLT (Bell, 2005; Brown, 2001; Nunan, 1989; Richards \& Rodgers, 2004). In order to assess the reliability of QCOLT, and to examine how well the test performed, a pilot study was conducted with 20 EFL teachers working in different private schools in Istanbul, Turkey. After the participants took the test, the researchers asked them, "Did you understand the test instructions? Were there any questions you did not understand? Do you object to the content of any questions?" As a result of the feedback received from the teachers, we deleted 6 items, and the revised version of the questionnaire with 50 items was created.

QCOLT consists of 50 items including two subscales: classroom events and communicative features. It is a 6-point Likert scale with anchors at $1=$ almost never, $2=$ rarely, $3=$ sometimes, $4=$ often, $5=$ usually, $6=$ almost always. In this study, the reliability of the instrument was found to be quite high, with Cronbach's alpha for Part A (classroom event) .80 and for Part B (communicative features) .70; the whole scale was .82 . 


\section{Procedure}

The pretest data collection began before the in-service education program was started. As a first step, we arranged a meeting with the teachers in each school. In those meetings, we informed the participants about the purpose of the study and told them that their participation was voluntary and they could withdraw from the study whenever they wanted. We also reassured them that all the information obtained from the questionnaires and observations would remain confidential. Then, we distributed the questionnaires (teachers' background questionnaire, QCOLT, and ESTES) to the participants and explained how to respond to them.

As the second step of the pretest data collection procedure, 20 volunteer teachers were observed. Each teacher was observed five times during a 40-minute English lesson by one of us, who sat at the back of the classroom and did not interact with the students at any time during the class. Every 5 minutes, we coded what was happening during the lesson into the observation form. Additional notes were also taken and at the same time the entire lesson was audiotaped. The same procedures were repeated to collect posttest data.

\section{RESULTS AND DISCUSSION}

\section{Findings Related to Research Question 1}

Pearson product-moment correlation was performed to explore the relationship between Turkish EFL teachers' efficacy and their selfreported practice of CLT. The results show no statistically significant relationship between teachers' efficacy (ESTES) and their self-reported practice of CLT (QCOLT). Also, no relationship among the dimensions of teacher efficacy and self-reported practice of CLT was discovered as a result of the analysis. Yet, a closer look at the data revealed that there was a significant relationship within the dimensions of teacher efficacy (ESTES; see Table 1). Efficacy for engaging students in learning EFL was significantly correlated with efficacy for managing EFL classes $(r=.617, p<.01)$ and with efficacy for implementing instructional strategies to teach EFL $(r=.415, p<.05)$. Moreover, there was a 
TABLE 1. The Relationship Between EFL Teachers' Efficacy and Self-Reported Practice of CLT

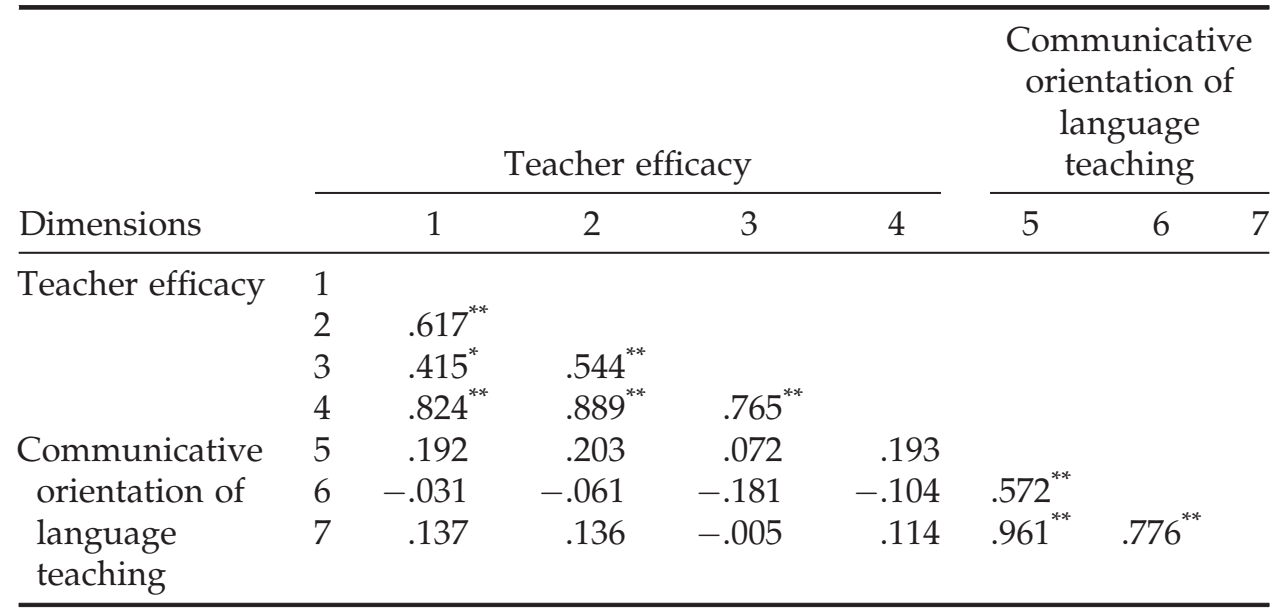

Note. 1 = efficacy for engaging students in learning EFL; 2 = efficacy for managing EFL classes; 3 = efficacy for implementing instructional strategies to teach EFL; 4 = teacher efficacy (overall); $5=$ classroom events (QCOLT Part A); 6 = communicative features (QCOLT Part B); $7=$ communicative orientation of language teaching (overall).

$* p<.05 ; * *<.01$.

substantial correlation between efficacy for managing EFL classes and efficacy for implementing instructional strategies to teach EFL $(r=.544, p<.01)$. Overall, teacher efficacy was significantly correlated with the three dimensions of efficacy for engaging students in learning EFL $(r=.824, p<.01)$, efficacy for managing EFL classes $(r=.889, p<.01)$, and efficacy for implementing instructional strategies to teach EFL $(r=.765, p<.01)$. In conclusion, the findings suggest that the more efficacious the teachers were in one of the dimensions of teacher efficacy, the more efficacious they would become overall.

There was also a significant relationship between the dimensions of QCOLT, classroom events, and communicative features $(r=.572, p<.01)$. Overall, teachers' self-reported practice of CLT was significantly correlated with classroom events $(r=.961, p<.01)$ and communicative features $(r=.776, p<.01$; see Table 1). In other words, as teachers' self-reported practice of CLT in terms of classroom events and/or communicative features increased, their overall use of CLT increased as well. 
TABLE 2. Pretest and Posttest Results on Teacher Efficacy (ESTES)

\begin{tabular}{|c|c|c|c|c|c|c|c|}
\hline \multirow[b]{2}{*}{ Teacher Efficacy } & \multicolumn{2}{|c|}{ Pretest } & \multicolumn{2}{|c|}{ Posttest } & \multicolumn{3}{|c|}{$t$-test } \\
\hline & $\bar{x}$ & $S D$ & $\bar{x}$ & $S D$ & $d f$ & $t$ & $p$ \\
\hline Student engagement & 27.58 & 6.86 & 30.20 & 3.58 & 49 & -2.977 & .005 \\
\hline Manag & 29.46 & 6.67 & 32.18 & 4.03 & 49 & -3.182 & .003 \\
\hline Instructional strategies & 30.32 & 5.99 & 32.34 & 3.19 & 49 & -2.662 & .010 \\
\hline Teacher efficacy (overall) & 87.36 & 16.96 & 94.72 & 8.98 & 49 & -3.569 & .001 \\
\hline
\end{tabular}

\section{Findings Related to Research Question 2}

In order to answer the second research question, the pretest and posttest results of ESTES, QCOLT, and COLT were analysed with paired samples $t$-tests.

The impact of in-service teacher education on Turkish EFL teachers' efficacy (ESTES). The findings demonstrated significant differences between the pretests and posttests of EFL teachers' efficacy $(p<.01)$ along with the differences in the dimensions of efficacy for student engagement $(p<.01)$, for management $(p<.01)$, and for instructional strategies efficacy $(p<.05$; see Table 2). Based on these findings, it can be suggested that the inservice teacher education program enabled the participating teachers to become more efficacious.

The impact of in-service teacher education on Turkish EFL teachers' self-reported practice of CLT (QCOLT). No significant difference was found between the pretests and posttests of the 50 Turkish EFL teachers' self-reported practice of CLT (Table 3).

The impact of in-service teacher education on Turkish EFL teachers' observed practice of CLT: COLT Part A (classroom events). The first category on COLT Part A is participant organization, which differentiates the activities in the classroom

TABLE 3. Pretest and Posttest Results on QCOLT

\begin{tabular}{|c|c|c|c|c|c|c|c|}
\hline \multirow[b]{2}{*}{ QCOLT } & \multicolumn{2}{|c|}{ Pretest } & \multicolumn{2}{|c|}{ Posttest } & \multicolumn{3}{|c|}{$t$-test } \\
\hline & $\bar{x}$ & $S D$ & $\bar{x}$ & $S D$ & $d f$ & $t$ & $p$ \\
\hline Classroom events & 149.20 & 27.90 & 156.02 & 15.56 & 49 & -1.536 & .131 \\
\hline Communicative features & 49.86 & 9.78 & 51.20 & 6.77 & 49 & -.775 & .442 \\
\hline QCOLT (overall) & 199.06 & 35.28 & 207.22 & 20.22 & 49 & -1.408 & .165 \\
\hline
\end{tabular}


TABLE 4. Pretest and Posttest Results on Participant Organization

\begin{tabular}{|c|c|c|c|c|c|c|c|}
\hline \multirow[b]{2}{*}{ Participant organization } & \multicolumn{2}{|c|}{ Pretest } & \multicolumn{2}{|c|}{ Posttest } & \multicolumn{3}{|c|}{$t$-test } \\
\hline & $\bar{x}$ & $S D$ & $\bar{x}$ & $S D$ & $d f$ & $t$ & $p$ \\
\hline Whole class & 56.22 & 24.14 & 50.00 & 21.45 & 19 & .855 & .403 \\
\hline Group work & 8.12 & 13.61 & 20.62 & 15.32 & 19 & -.162 & .005 \\
\hline Individual work & 35.62 & 24.76 & 29.37 & 25.73 & 19 & .763 & .455 \\
\hline
\end{tabular}

according to the way students are organized: whole-class, group, and individual work. As can be seen in Table 4, the pretest and posttest results of this category revealed a significant difference only in the aspect of group work $(p=.005)$. That is, after the in-service teacher education program, there was a statistically significant increase in teachers' use of group-work activities and a considerable decrease in the individual and whole-class activities. These findings partially confer the expectations of the in-service teacher education program which, among other CLT features, aimed at decreasing individual and whole-class activities while increasing group work.

The second category on COLT Part A is content, referring to the theme of the activities: management, language, and other topics. As presented in Table 5, the pretest and posttest results of this category showed a significant difference only in the aspect of management $(p=.003)$. That is, after the in-service teacher education program, teachers started to spend less time on management issues such as classroom procedure and discipline. This may result from students paying more attention to the flow of activities and being more interested in the tasks given to them. On

TABLE 5. Pretest and Posttest Results on Content

\begin{tabular}{lccccccccc}
\hline & \multicolumn{2}{c}{ Pretest } & & \multicolumn{2}{c}{ Posttest } & & \multicolumn{3}{c}{$t$-test } \\
\cline { 2 - 3 } Content & $\bar{x}$ & $S D$ & & $\bar{x}$ & $S D$ & & $d f$ & $t$ & $p$ \\
\hline Management & 25.62 & 15.95 & & 10.62 & 12.35 & & 19 & 3.405 & .003 \\
Language & 56.25 & 17.90 & & 65.00 & 18.40 & & 19 & -1.421 & .171 \\
Other topics & 18.12 & 11.08 & & 25.00 & 19.02 & & 19 & -1.291 & .212 \\
\hline
\end{tabular}


TABLE 6. Pretest and Posttest Results on Content Control

\begin{tabular}{|c|c|c|c|c|c|c|c|}
\hline \multirow[b]{2}{*}{ Content control } & \multicolumn{2}{|c|}{ Pretest } & \multicolumn{2}{|c|}{ Posttest } & \multicolumn{3}{|c|}{$t$-test } \\
\hline & $\bar{x}$ & $S D$ & $\bar{x}$ & $S D$ & $d f$ & $t$ & $p$ \\
\hline Teacher & 63.75 & 18.09 & 41.25 & 24.02 & 19 & 3.241 & .004 \\
\hline Teacher-student & 31.87 & 16.95 & 46.25 & 21.87 & 19 & -2.748 & .013 \\
\hline Student & 4.37 & 9.31 & 12.50 & 10.72 & 19 & -2.292 & .033 \\
\hline
\end{tabular}

the other hand, as Table 5 illustrates, teachers spent more time on the use of language (pre-lang $=56.250$; post-lang $=65.000$ ) and the discussion of topics related to the main topic (expansion; pre-other $=18.125$; post-other $=25.000$ ), but these findings were not significant. A possible explanation for these nonsignificant findings is that change is a difficult process that requires continuous support. According to Roberts (1998), "the personal and cognitive challenge of deep role change is far greater than fine-tuning. It, therefore, requires far more support, discussion, demonstration and long-term 'on-the-job' support" (p. 237). Thus, the participating teachers in this study might need further support to deeply change their practices.

The third category, content control, refers to the person selecting the topic (or task) of instruction and differentiates the control of content into three features: teacher control, teacher-student joint control, and only student control. As shown in Table 6, there were significant differences between the pretests and posttests of this category in the features of teacher control $(p=.004)$, teacherstudent joint control ( $p=.013)$, and student control $(p=.033)$. These results suggest that before the in-service teacher education program, teachers had more control over the content, but after the program, there was a significant increase in teacher-student joint control and students' control over the content. The changes in the category of content control were again one of the expectations of the in-service teacher education program, which aimed to involve students more in the processes of engaging in discussion and negotiation of meaning.

The fourth category on COLT Part A, student modality, identifies the four skills (listening, speaking, reading, and writing) 
TABLE 7. Pretest and Posttest Results on Student Modality

\begin{tabular}{|c|c|c|c|c|c|c|c|}
\hline \multirow[b]{2}{*}{ Student modality } & \multicolumn{2}{|c|}{ Pretest } & \multicolumn{2}{|c|}{ Posttest } & \multicolumn{3}{|c|}{$t$-test } \\
\hline & $\bar{x}$ & $S D$ & $\bar{x}$ & $S D$ & $d f$ & $t$ & $p$ \\
\hline One skill & 20.62 & 17.80 & 9.37 & 12.74 & 19 & 2.232 & .038 \\
\hline Three skills & 11.87 & 14.32 & 30.00 & 11.75 & 19 & -3.884 & .001 \\
\hline Four skills & 1.25 & 3.84 & 7.50 & 9.42 & 19 & -2.517 & .021 \\
\hline
\end{tabular}

and other language aspects (vocabulary and grammar) in which the students are engaged during the class. As presented in Table 7, the results indicated significant differences in the features of using only one skill $(p=.038)$, integrated three skills ( $p=.001)$, and four skills $(p=.021)$. In other words, teachers, after the in-service teacher education program, preferred to engage students in activities that required the use of integrated skills rather than focusing only on one skill or on grammar and vocabulary in isolation.

The impact of in-service teacher education on Turkish EFL teachers' observed practice of CLT: COLT Part B (communicative features). For the first category of target language, the findings demonstrated significant differences in teachers' use of L1 $(p=.001)$ and L1 translation $(p=.000)$. When the means were compared, it was seen that, after the in-service teacher education program, there was a decrease in teachers' use of L1 and L1 translation (see Table 8).

The second category of COLT Part B, information gap, aims to capture the extent to which the information requested or provided by the teachers is unpredictable. As presented in Table 9, the findings showed a significant difference only in the aspect of

TABLE 8. Pretest and Posttest Results on Target Language

\begin{tabular}{|c|c|c|c|c|c|c|c|}
\hline \multirow[b]{2}{*}{ Target language } & \multicolumn{2}{|c|}{ Pretest } & \multicolumn{2}{|c|}{ Posttest } & \multicolumn{3}{|c|}{$t$-test } \\
\hline & $\bar{x}$ & $S D$ & $\bar{x}$ & $S D$ & $d f$ & $t$ & $p$ \\
\hline L1 & 10.90 & 6.51 & 5.55 & 6.99 & 19 & 4.076 & .001 \\
\hline L1 translation & 1.95 & 5.09 & 0.50 & 2.23 & 19 & -4.812 & .000 \\
\hline $\mathrm{L} 2$ & 86.40 & 7.90 & 93.75 & 7.07 & 19 & 1.281 & .216 \\
\hline
\end{tabular}


TABLE 9. Pretest and Posttest Results on Information Gap

\begin{tabular}{|c|c|c|c|c|c|c|c|}
\hline \multirow[b]{2}{*}{ Information gap } & \multicolumn{2}{|c|}{ Pretest } & \multicolumn{2}{|c|}{ Posttest } & \multicolumn{3}{|c|}{$t$-test } \\
\hline & $\bar{x}$ & $S D$ & $\bar{x}$ & $S D$ & $d f$ & $t$ & $p$ \\
\hline Predictable information & 25.75 & 13.87 & 20.50 & 9.43 & 19 & 1.341 & 196 \\
\hline Unpredictable information & 25.65 & 14.25 & 29.75 & 11.78 & 19 & -1.129 & .273 \\
\hline Pseudo questions & 22.05 & 10.76 & 21.05 & 8.78 & 19 & 0.303 & .765 \\
\hline Genuine questions & 23.35 & 8.58 & 28.70 & 5.71 & 19 & -2.383 & .028 \\
\hline
\end{tabular}

teachers' asking genuine questions $(p=.028)$. That is, after the in-service teacher education program, teachers asked students more genuine questions to foster authentic communication in the classroom.

The third category in COLT Part B differentiates teachers' speech as ultra-minimal, minimal, and sustained. As shown in Table 10, there were significant differences in teachers' use of ultra-minimal $(p=.004)$ and minimal speech $(p=.043)$. A comparison of the means revealed that, after the in-service teacher education program, teachers provided less ultra-minimal but more minimal speech in the classroom. That is, the teachers did not give feedback just to indicate the student was right or wrong but tried to establish meaningful communication with the students.

The fourth category refers to the ways teachers react to student's utterances. The COLT observation scheme proposes seven selected reactions to preceding utterances: correction, repetition, paraphrase, comment, expansion, clarification request, and elaborative request. COLT Part B also has a category of reaction to form/message, which intends to measure whether

TABLE 10. Pretest and Posttest Results on Sustained Speech

\begin{tabular}{|c|c|c|c|c|c|c|c|}
\hline \multirow[b]{2}{*}{ Teachers' speech } & \multicolumn{2}{|c|}{ Pretest } & \multicolumn{2}{|c|}{ Posttest } & \multicolumn{3}{|c|}{$t$-test } \\
\hline & $\bar{x}$ & $S D$ & $\bar{x}$ & $S D$ & $d f$ & $t$ & $p$ \\
\hline Ultra-minimal & 14.50 & 12.65 & 5.40 & 7.42 & 19 & 3.309 & .004 \\
\hline Minimal & 59.65 & 12.25 & 68.10 & 12.43 & 19 & -2.174 & .043 \\
\hline Sustained & 25.55 & 8.40 & 26.00 & 14.03 & 19 & -0.124 & .903 \\
\hline
\end{tabular}


TABLE 11. Pretest and Posttest Results on Reaction to Form/Message and Incorporation of Student/Teacher Utterances

\begin{tabular}{|c|c|c|c|c|c|c|c|c|}
\hline \multirow[b]{2}{*}{ Reaction } & \multirow{2}{*}{$\begin{array}{c}\text { Incorporating } \\
\text { student/ } \\
\text { teacher } \\
\text { utterances }\end{array}$} & \multicolumn{2}{|c|}{ Pretest } & \multicolumn{2}{|c|}{ Posttest } & \multicolumn{3}{|c|}{$t$-test } \\
\hline & & $\bar{x}$ & $S D$ & $\bar{x}$ & $S D$ & $d f$ & $t$ & $p$ \\
\hline \multirow[t]{2}{*}{ Meaning } & $\begin{array}{l}\text { Clarification } \\
\text { request }\end{array}$ & 9.00 & 8.82 & 16.95 & 10.90 & 19 & -2.344 & .030 \\
\hline & $\begin{array}{l}\text { Elaborative } \\
\text { request }\end{array}$ & 13.35 & 7.45 & 19.00 & 9.67 & 19 & -2.249 & .037 \\
\hline Form & Correction & 9.25 & 11.27 & 2.00 & 3.76 & 19 & 2.759 & .012 \\
\hline
\end{tabular}

teachers react to the message or form of students' utterances. While coding, these two categories are combined to decide whether the focus is on form or message whenever a category under incorporation of student/teacher utterances is checked.

As can be seen in Table 11, the analysis of the pretests and posttests of these categories showed significant differences in the features of form-focused correction ( $p=.012)$, message-focused clarification ( $p=.030)$, and elaborative request $(p=.037)$. That is, after the in-service teacher education program, the teachers reacted to students' utterances by providing less form-focused correction and more meaning-focused elaborative and clarification requests. No significant difference was found in the categories of messagefocused repetition, paraphrase, comment, expansion, and formfocused repetition. These findings again can be explained by the fact that teachers might need more time and further support during the process of change.

As argued by Roberts (1998), an implementation of an innovation requires more than a change in replacing old materials or old practices with the new ones. Instead, teacher change is an evolutionary process which happens through trial and error. In this respect, the findings of the present study must be interpreted with caution because they revealed both statistically significant and nonsignificant changes in teachers' self-reported as well as observed practice of CLT. These results might imply that these teachers are in the process of change and they need continuous support to strengthen these changes in their beliefs and practices. 


\section{DISCUSSION AND CONCLUSION}

In relation to the first research question ("What is the relationship between Turkish EFL teachers' efficacy and their self-reported teaching behaviour in the class?"), findings indicated no significant relationship between the teachers' efficacy and their self-reported practice of CLT. In other terms, in this study, Turkish EFL teachers' efficacy did not vary in accordance with their selfreported classroom practice. Similarly, in Chacon's (2005) study, it was found that teacher efficacy did not seem to have a significant relationship with teachers' self-reported practice of teaching. Hence, a possible explanation for these results might be that teachers may not be evaluating their teaching practices as grammar-oriented or communicative-oriented when they make decisions about their teacher efficacy.

On the other hand, the dimensions of teacher efficacy - efficacy for engaging students in learning EFL, efficacy for managing EFL classes, and efficacy for implementing instructional strategies to teach EFL-were found to be significantly related to each other and with overall teacher efficacy. That is, the teachers who reported to be efficacious in one dimension of teacher efficacy also tended to be efficacious in the other two dimensions and as a result became more efficacious overall. In a similar way, as teachers' self-reported practice of CLT in terms of classroom events increased (e.g., roleplays, discussions and debates, group-work activities, use of conversational strategies), their self-reported practice of CLT in terms of communicative features (e.g., asking genuine questions, exchanging information, paraphrasing, extensions of the content) and their overall self-reported practice of CLT increased as well. These findings concur with the results of Tschannen-Moran and Woolfolk Hoy's (2001) study, which indicates that the correlations within the dimensions of both teacher efficacy and behaviour scales were much stronger than the correlations between any teacher efficacy and behaviour scale.

In relation to the second research question ("To what extent does the in-service teacher education program influence Turkish EFL teachers' efficacy and their self-reported and observed teaching behaviour in the class?"), the findings first suggested that 
the in-service teacher education program enhanced Turkish EFL teachers' efficacy. In this respect, this study produced results which corroborate the findings of a great deal of previous work that provides evidence for the positive impact of various professional development activities such as mentoring or teacher research on teacher efficacy (Eun \& Heining-Boynton, 2007; Fritz, 1995; Henson, 2001; Yost, 2002).

Second, the findings revealed that the in-service teacher education program did not seem to have a significant impact on teachers' overall self-reported practice of CLT. However, the findings still suggested that the program encouraged the participating teachers to foster more real-life use of language by increasing students' use of conversational strategies, by using less immediate error correction, and by encouraging students' initiation and contribution to classroom discussions.

Similarly, significant differences were observed in certain aspects of teachers' observed practice of CLT before and after the in-service teacher education program. Specifically, after the program less teacher control and more student involvement in classroom activities, more use of activities that encouraged students to use more than one mode of communication in English (i.e., integration of skills) through group work, and more focus on meaning rather than form were found in teachers' practices. In other words, the changes in all of the above-mentioned features suggest a shift from traditional grammar-based activities to more communicative ones as a result of the in-service teacher education program which, in fact, aimed to improve these aspects of CLT in teachers' practices. The findings which illustrate the impact of the in-service teacher education program on certain aspects of teachers' self-reported and observed practice of CLT rather than their overall practice of CLT support the fact that teacher change is a difficult process that needs long-term support (Akyel, 2000). This finding is compatible with the social constructivist background of the in-service teacher education program, because it provides evidence for how teacher development occurs in constant exchange with the environment by reframing beliefs and teaching practice with the help of input and feedback (Williams \& Burden, 1997). In this sense, the findings of this study concerning the 
importance of dialogue and collaboration with colleagues concur with the findings of other studies in the field (Akyel, 2000;

Davydov, 1995; Kauchak \& Eggen, 1997).

\section{Implications}

The findings which indicate the positive impact of the in-service teacher education program on teachers' efficacy and their teaching behaviour not only provide insights into the features of effective professional development activities and how they can contribute to teachers' beliefs and practice, but also present evidence for Bandura's (1997) four sources of efficacy: enactive mastery experiences, vicarious experiences, verbal persuasion, and physiological and affective states. The present study also provides additional empirical evidence for the reliability and validity for the English Teachers' Sense of Efficacy Scale (Chacon, 2005) by replicating the original findings with a totally different sample.

Finally, by investigating teachers' in-class teaching behaviour with a self-report instrument as well as through observations, this study highlights the need for classroom observations to see the extent to which these beliefs concur with teachers' behaviour. The findings also point out the importance of awareness-raising activities in investigating the relationship between teachers' beliefs and practices. In this respect, this study highlights the importance of using multiple instruments to examine teachers' beliefs and practices.

\section{Limitations and Recommendations for Further Research}

This study collected data on teachers' efficacy and their practices through surveys and observations. Therefore, there is a lack of qualitative evidence on the implementation of professional development program within and across schools. Future research should consider exploring teacher efficacy and practices both qualitatively and quantitatively to explore the way individual teachers with varying efficacies and instructional behaviours react to professional development activities.

Another limitation of this study is that it focused on Turkish EFL teachers who worked in eight purposefully selected schools in Istanbul, Turkey. Therefore, the results may not be generalizable to 
other EFL settings. Because teacher efficacy is a multifaceted construct that varies across tasks and contexts, this study should be replicated in different settings with teachers coming from diverse backgrounds. Examining the differences between native and nonnative EFL teachers will also bring about insights into the studies of teacher efficacy. Finally, more experimental studies are required to estimate the long-term effects of in-service teacher education programs on EFL teachers' efficacy and their selfreported and observed practice of CLT.

In conclusion, the significant improvements not only in teachers' self-reported and observed practice of communicative language teaching, but also in their teacher efficacy as evidenced by the study's findings shed light on the aspects of effective professional development programs and the way they influence teachers' beliefs and practices especially in EFL contexts such as Turkey where English is not routinely used for communication outside the classroom and teachers are the only source of input for language learning.

\section{THE AUTHORS}

Deniz Ortaçtepe, after receiving her doctorate in curriculum and instruction at the State University of New York-Albany, started working as an assistant professor in the MA TEFL program at Bilkent University, in Ankara, Turkey. Her research interests are language socialization, intercultural pragmatics, and sociolinguistics.

Ayşe S. Akyel is a professor in the Department of Foreign Language Education at Yeditepe University, in Istanbul, Turkey, where she is also the dean of the Faculty of Education. Her research interests include teacher education and professional development, teacher cognition, approaches to teaching language skills, and content-based instruction.

\section{REFERENCES}

Akyel, A. (2000). Collaboration to explore teaching: A case study report. TESL Canada Journal, 18(1), 58-74. 
Ary, D., Jacobs, L. C., Razavieh, A., \& Sorensen, C. (2006).

Introduction to research in education (7th ed.). Independence, KY: Cengage.

Bandura, A. (1997). Self-efficacy: The exercise of control. New York, NY: W. H. Freeman.

Bax, S. (2003). The end of CLT: A context approach to language teaching. ELT Journal, 57(3), 278-287.

Bell, T. R. (2005). Behaviours and attitudes of effective foreign language teachers: Results of a questionnaire study. Foreign Language Annals, 38, 259-270. doi:10.1111/j.1944-9720. 2005.tb02490.x

Betoret, F. D. (2006). Stressors, self-efficacy, coping resources, and burnout among secondary school teachers in Spain. Educational Psychology, 26, 519-539. doi:10.1080/01443410500342492 Bransford, J., Darling-Hammond, L., \& LePage, P. (2005).

Introduction. In J. Bransford \& L. Darling-Hammond (Eds.), Preparing teachers for a challenging world: What teachers should learn and be able to do (pp. 1-39). San Francisco, CA: Jossey-Bass. Brown, H. D. (2001). Teaching by principles: An interactive approach to language pedagogy. New York, NY: Longman.

Byram, M., Gribkova, B., \& Starkey, H. (2002). Developing the intercultural dimension in language teaching: A practical introduction for teachers. Strasbourg, France: Council of Europe, Language Policy Division.

Çakıroğlu, J., Çakıroğlu, E., \& Boone, W. J. (2005). Pre-service teacher self-efficacy beliefs regarding science teaching: A comparison of pre-service teachers in Turkey and the USA. Science Educator, 14(1), 31-41.

Campbell, J. (1996). A comparison of teacher efficacy for pre- and in-service teachers in Scotland and America. Education, 117(1), 2-11.

Chacon, T. C. (2005). Teachers' perceived efficacy among English as a foreign language teachers in middle schools in Venezuela. Teaching and Teacher Education, 21, 257-272. doi:10.1016/ j.tate.2005.01.001

Coladarci, T. (1992). Teachers' sense of efficacy and commitment to teaching. Journal of Experimental Education, 60, 323-337. doi:10.1080/00220973.1992.9943869 
Coşkun, A. (2011). Investigation of the application of communicative language teaching in the English language classroom: A case study on teachers' attitudes in Turkey. Journal of Linguistics and Language Teaching, 2(1), 1-27.

Davydov, V. V. (1995). The influence of L. A. Vygotsky on education, theory, research and practice. Educational Researcher, 24(3), 12-23. doi:10.3102/0013189X024003012

Eun, B., \& Heining-Boynton, A. L. (2007). Impact of an English-asa-second-language professional development program. Journal of Educational Research, 101, 36-48. doi:10.3200/JOER.101.1.36-49 Freeman, D., \& Johnson, K. E. (1998). Reconceptualizing the knowledge-base of language teacher education. TESOL Quarterly, 32, 397-417. doi:10.2307/3588114

Fritz, J. J. (1995). Fostering personal teaching efficacy through staff development and classroom activities. The Journal of Educational Research, 88(4), 200-208.

Ghaith, G., \& Yaghi, H. (1997). Relationship among experience, teacher efficacy and attitudes toward the implementation of instructional innovation. Teaching and Teacher Education, 13, 451-458. doi:10.1016/S0742-051X(96)00045-5

Hall, G. (2011). Exploring English language teaching: Language in action. New York, NY: Routledge.

Henson, R. K. (2001). The effects of participation in teacher research on teacher efficacy. Teaching and Teacher Education, 17, 819-836. doi:10.1016/S0742-051X(01)00033-6

Inceçay, G., \& Inceçay, V. (2009). Turkish university students' perceptions of communicative and non-communicative activities in EFL classroom. Procedia-Social and Behavioral Sciences, 1(1), 618-622. doi:10.1016/j.sbspro.2009.01.110 Kauchak, D. P., \& Eggen, P. H. (1997). Learning and teaching methods. Boston, MA: Allyn and Bacon.

Kırkgöz, Y. (2008). A case study of teachers' implementation of curriculum innovation in English language teaching in Turkish primary education. Teaching and Teacher Education, 24, 18591875. doi:10.1016/j.tate.2008.02.007

Klassen, R. M., Tze, V. M. C., Betts, S. M., \& Gordon, K. A. (2011). Teacher efficacy research 1998-2009: Signs of progress or 
unfulfilled promise? Educational Psychology Review, 23, 21-43. doi:10.1007/s10648-010-9141-8

Larsen-Freeman, D. (2003). Techniques and principles in language teaching (2nd ed.). Oxford, England: Oxford University Press. Lohman, M. C. (2000). Environmental inhibitors to informal learning in the workplace: A case study of public school teachers. Adult Education Quarterly, 50(2), 83-101. doi:10.1177/ 07417130022086928

Murray, D. E., \& Christison, M. (2011). What English language teachers need to know, Volume 1: Understanding learning. London, England: Routledge.

Nunan, D. (1989). Designing tasks for the communicative classroom. Cambridge, England: Cambridge University Press.

Pajares, F. (1992). Teachers' beliefs and educational research:

Cleaning up a messy construct. Review of Educational Research, 62, 307-332. doi:10.3102/00346543062003307

Richard-Amato, P. (2003). Making it happen: From interactive to participatory language teaching. White Plains, NY: Pearson Education.

Richards, J., \& Farrell, T. (2005). Professional development for language teachers: Strategies for teacher learning. New York, NY: Cambridge University Press.

Richards, J., \& Rodgers, T. S. (2004). Approaches and methods in language teaching (2nd ed.). New York, NY: Cambridge University Press.

Roberts, J. (1998). Language teacher education. London, England: Arnold.

Ross, J., \& Bruce, C. (2007). Professional development effects on teacher efficacy: Results of randomized field trial. Journal of Educational Research, 101, 50-60. doi:10.3200/JOER.101.1.50-60 Savran-Gencer, A., \& Çakıroğlu, J. (2007). Turkish preservice science teachers' efficacy beliefs regarding science teaching and their beliefs about classroom management. Teaching and Teacher Education, 23, 664-675. doi:10.1016/j.tate.2005.09.013

Shim, J. (2001). The teacher efficacy beliefs of Korean teachers of English as a foreign language (Unpublished doctoral dissertation). Ohio State University, Columbus, Ohio. 
Skaalvik, E. M., \& Skaalvik, S. (2010). Teacher self-efficacy and teacher burnout: A study of relations. Teaching and Teacher Education, 26, 1059-1069. doi:10.1016/j.tate.2009.11.001 Spada, N., \& Frönlich, M. (1995). Communicative orientation of language teaching observation scheme coding conventions and applications. Sydney, Australia: Macquarie University, NCELTR. Tournaki, N., \& Podell, D. M. (2005). The impact of student characteristics and teacher efficacy on teachers' predictions of student success. Teaching and Teacher Education, 21, 299-314. doi:10.1016/j.tate.2005.01.003

Tschannen-Moran, M., \& Barr, M. (2004). Fostering student learning: The relationship of collective teacher efficacy and student achievement. Leadership and Policy in Schools, 3(3), 189-209. doi:10.1080/15700760490503706

Tschannen-Moran, M., \& Woolfolk-Hoy, A. (2001). Teacher efficacy: Capturing an elusive construct. Teaching and Teacher Education, 17, 783-805. doi:10.1016/S0742-051X(01)00036-1 Tschannen-Moran, M., Woolfolk Hoy, A., \& Hoy, W. K. (1998). Teacher efficacy: Its meaning and measurement. Review of Educational Research, 68, 202-248. doi:10.3102/0034654 3068002202

Vygotsky, L. S. (1978). Mind in society: The development of higher psychological process. Cambridge, MA: Harvard University Press. Williams, M., \& Burden, R. L. (1997). Psychology for language teachers: A social constructivist approach. New York, NY: Cambridge University Press.

Woolfolk, A. E., \& Hoy, W. K. (1990). Prospective teachers' sense of efficacy and beliefs about control. Journal of Educational Psychology, 82, 81-91. doi:10.1037//0022-0663.82.1.81

Woolfolk Hoy, A., \& Burke Spero, R. (2005). Changes in teacher efficacy during the early years of teaching: A comparison of four measures. Teaching and Teacher Education, 21, 343-356. doi:10.1016/j.tate.2005.01.007

Yost, R. (2002). "I think I can": Mentoring as a means of enhancing teacher efficacy. The Clearing House, 75(4), 195-197. doi:10.1080/ 00098650209604930 